\title{
Environmental ethics, environmental performance, and competitive advantage: Role of environmental training
}

\author{
Sanjay Kumar Singh ${ }^{\mathrm{a}, *}$, Jin Chen ${ }^{\mathrm{b}}$, Manlio Del Giudice ${ }^{\mathrm{c}, \mathrm{d}}$, Abdul-Nasser El-Kassar ${ }^{\mathrm{e}}$ \\ ${ }^{\text {a }}$ College of Business, Abu Dhabi University, Abu Dhabi, United Arab Emirates \\ ${ }^{\mathrm{b}}$ School of Economics and Management, Tsinghua University, Beijing, China \\ ' University of Rome "Link Campus", Italy \\ ${ }^{\mathrm{d}}$ Paris School of Business, Paris, France \\ e Adnan Kassar School of Business, Lebanese American University, Beirut, Lebanon
}

\section{A R T I C L E I N F O}

\section{Keywords:}

Resource-based view

Dynamic capabilities

Environmental ethics

Environmental training

Environmental performance

Competitive advantage

\begin{abstract}
A B S T R A C T
In an era of increased stakeholder pressure for sustainable environmental management practices at workplace, organization should adopt and implement environmental ethics for seamless synergy amongst the needs of the business, the society, and the planet. Our study used resource-based view (RBV) and dynamic capabilities (DC) theoretical lenses to examine hypotheses derived from extant literature on the linkages amongst environmental ethics, environmental training, environmental performance and competitive advantage. Using survey questionnaire, we employed structural equation modeling (SEM) on 364 valid responses from managers to examine the hypotheses. The findings of our study will stir up researcher's curiosity to unravel the human side of environmental management and that will surely steer future researches in significant directions. Results suggest that environmental ethics influences environmental training, environmental performance and competitive advantage. We also found that environmental training to employees mediates the influence of environmental ethics on firm's environmental performance and competitive advantage. The findings of the study implies that organizational approach towards environmental ethical practices at workplace should be not be reactive but proactive with intentions to create and sustain synergy amongst the triads namely, profits, the society, and the environment. Environmental training should not be one-off event but a continuous process to beat competitions and improve environmental performance in the organization.
\end{abstract}

\section{Introduction}

The economic activities of firms always have other side to it - the ecological imbalance. Lately the firms have been witnessing greater stakeholders pressure to reduce the environmental impact created out of their business related activities (Longoni et al., 2018; Yu et al., 2017). As a result, firms are not only supposed to espouse environmental values to secure sustainable economic success (Tate and Bals, 2018) but they should view environmental management as measure of their 'social performance' (Short et al., 2016; Yawar and Seuring, 2017). That calls upon organizational leaders to be committed to environmental ethics through policy formulation and their implementation in day-today operations to reduce the environmental impact of business operations, if any (El-Kassar and Singh, 2018; Singh and El-Kassar, 2019). Several studies suggest that firm's environmental performance depends upon their human resources' sensitivity to environmental issues \& possess specific green competencies related to core businesses for organizational usages in their value creation processes (El-Kassar and Singh, 2018; Guerci et al., 2016; Singh and El-Kassar, 2019). Therefore, we contemplate that the implementation of organizational intentions to 'go green' and manage environmental performance depends largely upon human resources across functions along with supportive HR systems \& processes to effectively manage employee-related issues (Guerci et al., 2016; Nejati et al., 2017; Renwick et al., 2013).

The extant literature also suggest for hiring candidates who demonstrate environmental knowledge and motivation (Jabbour et al., 2010) useful enough to enhance environmental performance as the later influences firm's competitive advantage (Chuang and Huang, 2018; Famiyeh et al., 2018). Several colleagues have highlighted about the role of leadership (Dubey et al., 2015), top management commitment (Dubey et al., 2017), organizational culture (Dubey et al., 2017; Sugita and Takahashi, 2015), corporate environmental strategy (Chen

\footnotetext{
* Corresponding author.

E-mail addresses: sanjay.singh@adu.ac.ae (S.K. Singh), chenjin@sem.tsinghua.edu.cn (J. Chen), manlio.delgiudice@oasipc.com (M. Del Giudice), abdulnasser.kassar@lau.edu.lb (A.-N. El-Kassar).
} 
et al., 2015), and employee's environmental involvement (Chen et al., 2015) on the firm environmental performance. However, we argue that firms should keep their employees updated about emerging environmental niceties through concerted environmental training to develop their green skills, knowledge and attitude for augmenting environmental performance and competitive advantage. The environmental training to employees influences their in-role green behavior (Dumont et al., 2017) and explain the linkage between firm's environmental management and performance (Guerci et al., 2016; O'Donohue and Torugsa, 2016). Having said that, the extant literature has given scant attention to the role of employee's environmental training vis-à-vis environmental performance, though some recent studies have made attempt to fill in the void (El-Kassar and Singh, 2018; Singh and ElKassar, 2019) but it requires more research work to strengthen the nascent knowledge domain of employee's environmental training vis-àvis firm environmental performance and management.

Employee's environmental training has root in an environmental sustainability philosophy within that aims to develop employee's abilities, motivation, commitment and involvement towards firms' environmental goals (O'Donohue and Torugsa, 2016). We contend that environmental training affects employee's in-role and extra-role workplace green behavior (Dumont et al., 2017) necessary for helping firms to enhance their environmental performance and competitive advantage. Drawing upon literature in other knowledge domain, we posit that training \& development (T\&D) is an important HR tool to enhance employee's competence and commitment and that, in turn to, influences firm innovative performance (Sung and Choi, 2018). To fill the void in the employee's environmental training and environmental management \& performance literature, our study proposes a cohesive research framework with empirical evidence that ascertains that environmental training mediates the influence of environmental ethics on environmental performance and competitive advantage.

Our study makes three key contributions to advance environmental sustainability philosophy and arrest environmental impact of business operations, if any. Firstly, our study contributes to advance nascent knowledge on the role of employee's environmental training vis-à-vis environmental performance and competitive advantage. Secondly, we contribute to fill the void on the critical role of employee's environmental training in facilitating firm's environmental ethics to influence its environmental performance and competitive advantage. Last, but not the least, our study advances the aim of Technological Forecasting and Social Change journal to provide policy makers and practitioners with forecasting tool on how to leverage corporate environmental ethics to augment environmental performance and competitive advantage for securing sustainable economic success.

We have arranged our paper as follows. Section 2 presents theory and hypotheses formulation to be examined empirically followed by Section 3 on the methods used in this study. We present results of the study in Section 4 and Section 5 details discussion \& conclusion of the study.

\section{Theory and hypotheses}

\subsection{The resource-based \& dynamic capabilities view}

The RBV effectively puts "human resource" on the strategy radar screen (Snell et al., 2001b), as a firm's competitive advantage emanates from aligning human resources skills, motives, and attitudes with organization's systems, processes, and practices (Teece, 2014). We posit that RBV influenced in establishing a macro perspective in the domain of human resource management (HRM) researches (Snell et al., 2001a, 2001b); and in a way, the macro view provides complementary depth to a traditionally micro discipline as enunciated in psychology. The evident and robustly established macro perspective in HRM research is considered a major influence of RBV (Snell et al., 2001a, 2001b). RBV has played a key role in legitimating the relevance of human resources and their management vis-à-vis researches in the field of strategic management of all key organizational resources, including the human resources, for firm performance and competitive advantage (Wright et al., 2001). Furthermore, RBV suggests that competitive advantage emanates from aligning motives, skills and attitudes of employees with organization's systems, processes, and practices to develop dynamic capabilities at firm level (Teece, 2007). Therefore, we argue that the people aspect of organization has been at the core of the RBV of the firm towards its continuous journey for competitive advantage in a given market.

At the same time, we posit that the dynamic capabilities (DC) in combination with the RBV provides bigger and better theoretical lens to examine how firm should use dynamic managerial skills, attitudes, and competencies to enhance their performance and competitive advantage. The extant literature suggest for rising interest amongst colleagues to use dynamic capabilities perspective towards management and development of human resources in the organizations (Helfat and Peteraf, 2015; Teece, 2014). Drawing upon the DC, we posit that to convert corporate environmental ethics into practice, firms always need key dynamic capabilities of sensing, seizing, and transforming to develop and hone employee's cognitive and affective capacities for augmenting both the environmental performance and the competitive advantage (e.g., Teece, 2007, 2014). We argue that the DC is the sum total ability of a firm to effectively integrate, build and reconfigure their competences (i.e., environmental ethics and employee's environmental skills, knowledge and attitudes) (Teece, 2007, 2014), especially when key stakeholders pushes firms to 'go green' in its processes, products and services that they offer to their customers. Therefore, the firms should sense and seize opportunities as well as challenges and transform their employees with skills and competencies through concerted environmental training to help firms effectively execute environmental ethical policy into practices (e.g., Eisenhardt and Martin, 2000) due to pressures from the key stakeholders. We posit environmental skills as dynamic managerial capabilities that helps people at workplace to integrate and reconfigure firm resources and competencies (Adner and Helfat, 2003) necessary to reduce negative effect of their business actions, if any, on built and physical environment.

We posit that organization with environmental management goals uses the dynamic human capabilities namely, green skills, knowledge, and attitudes for not only attaining environmental performance but also to enhance their green core competence through constant rearrangement and adaptation vis-à-vis increasing demands from environmentally aware stakeholders (e.g., Jabbour et al., 2019; Wang et al., 2012). As a result, we contemplate that environmental training enhances employees' capabilities for sensing and seizing available opportunities to minimize negative impact of business operations on natural and built environment, if any, and act as a source of path dependence to environmental performance and competitive advantage. Therefore, drawing upon the RBV and the DC perspectives, we argue that environmental training enhances employees' dynamic capabilities namely, green skills, attitudes and knowledge to be leveraged by firms while sensing and seizing opportunities to enhance their competitive advantage and environmental performance (e.g., Schilke, 2014; Vogel and Güttel, 2013).

\subsection{Environmental ethics and competitive advantage}

The ethical beliefs, values, and norms for environmental concerns symbolizes corporate environmental ethics (Ahmed et al., 1998) that may result in to long-term economic gains for firms. Firm's environmental ethics indicates about their intentions and purpose to proactive environmental management (Weaver et al., 1999) and is one of the fundamental components of organizational culture (Peng and Lin, 2008) that is associated with environmental performance and competitive advantage. The firm's environmental ethical policy helps formalize values and expectations for ethical behaviors and that has 
influence over their environmental performance and competitive advantage (Chang, 2011). We argue that firm environmental ethics positively affect competitive advantage as they help not only to meet environmental regulations (Chang, 2011). Organizations that practices high standards of environmental ethics avoid troubles, if any, that come with environmental protection protests and at the same time improve their corporate image (Chen et al., 2006).

Using RBV and DC view of the firm, we base our argument in a manner that competitive advantage emanates when firms align employees' motives, skills and attitudes with systems, processes, and practices to develop dynamic capabilities at firm level (Teece, 2007). Therefore, we posit that environmental ethics is an intangible asset that the firms can leverage to enhance their competitive advantage (Chang, 2011; Chen, 2008). The environmental management requires changes in routines and operations (Aragón-Correa et al., 2008) and is obviously an organizational competency (Christmann, 2000), and that result in reducing environmental impacts, if any, and concurrently maintain or increase organization's competitiveness (Tate and Bals, 2018). Therefore, we predict that:

Hypothesis 1 (H1). Environmental ethics influences competitive advantage.

\subsection{Environmental ethics and environmental performance}

Environmental ethics is an important internal resource that allow firm to employ a value-creating strategy (Barney, 1991) for enhancing environmental performance. Environmental performance refers to the organization's behavior vis-à-vis natural environment in terms of how it goes about to consume available resources with strong commitment to have strict check on pollution emissions, if any (Wagner et al., 2002). Drawing upon the RBV, we argue that firms have natural tendency to arrange for value-creating strategies to create synergy amongst their internal resources including environmental ethics to enhance their environmental performance along with outperforming their competitors in the markets (e.g., Ployhart, 2012). Furthermore, we contend that corporate environmental ethics of firms influences proactive environmental actions on their part and that to impact environmental performance (Chang, 2011; Chen et al., 2006; Porter and van der Linde, 1995).

Environmental performance encompasses insertion of biodegradable ingredients in products, reduction pollution and waste at source, reduction of environmentally harmful materials, enhancements in energy efficiency, and more (Zhu et al., 2010). Environmental performance not only affects organization's social acceptability, but also a basis of competitive advantage (Kassinis and Vafeas, 2006). That calls upon organizations to make environmental management "a ubiquitous philosophy of organization wherein all people are engaged in greening the firm" (Sarkis et al., 2010, p. 163). Furthermore, several past studies suggest for integration of environmental values into firms' environmental strategies, strategic planning processes, and organizational culture to foster environmental performance (Alt et al., 2015; Anton et al., 2004; Chan, 2005; Jabbour, 2015). Using the RBV, we posit that corporate environmental ethics being a valued and rare resources that act on firm (Teece, 2007; Wright et al., 2001) to inbuilt environmental philosophy as a way of life in managing people, processes and products in a manner that enhances their environmental performance. Therefore, we propose that:

Hypothesis 2 (H2). Environmental ethics influences environmental performance.

\subsection{Environmental ethics and environmental training}

Extant literature suggest that stakeholders pressures push firms to have in place environmental ethical policies and practices (Lee et al.,
2018) and make employees to practice it not at superficial level but to make it part of regular their job behaviors (Abdelzaher and Abdelzaher, 2017) as environmental ethics promotes green innovations in the organization (Chang, 2011; El-Kassar and Singh, 2018). In this context, the role of environmental training become critical to develop green skills, knowledge and attitudes of employees vis-à-vis firm's environmental performance (El-Kassar and Singh, 2018; Ji et al., 2012; Renwick et al., 2013). Several studies indicate that environmental training enhances employees' green competencies necessary for the implementing environmental management system (Delmas and Pekovic, 2013) to achieve environmental performance goals of the organization (Daily et al., 2012; El-Kassar and Singh, 2018). We posit that corporate environmental ethics act upon firm's human resource management practices to provide environmental training to employees to develop and sharpen their environmental attitudes and knowledge to help attain firms environmental performance (Longoni et al., 2018; Renwick et al., 2013). Using RBV and DC, we contend that environmental training make employees aware of firms' environmental ethics and goals (Longoni et al., 2018; Singh and El-Kassar, 2019) that help organization to reduce negative effect of business operations, if any, on the physical environment (El-Kassar and Singh, 2018; Graves et al., 2013) and enhance their environmental performance (Singh and ElKassar, 2019; Thu et al., 2019). Therefore, corporate environmental ethical policy drives environmental training to employees; and as a result, we predict that:

Hypothesis 3 (H3). Environmental ethics influences environmental training.

\subsection{Environmental training, environmental performance and competitive advantage}

The environmental training to employees have become buzz word and grown in relevance (Longoni et al., 2018; Singh and El-Kassar, 2019) as it enhances firm's environmental performance and competitiveness but still in its infancy and that calls for further researches. In the era of increasing pressure from varied stakeholders, the firms needs to manage external pressures with dynamic internal capabilities and the environmental training to employees become an important tool to handle such pressure and that in turn influences organization's environmental performance and competitive advantage in the markets (e.g., Jabbour, 2015; Longoni et al., 2018; Sarkis et al., 2010). The management and development of the employees have been an important element of firm's environmental management agenda (Cassells and Lewis, 2017; Daily et al., 2012; Jabbour, 2015; Sarkis et al., 2010).

Extant literature suggest that employees' environmental behavior drives and improves firm's environmental orientation, competitiveness and performance (Boiral et al., 2015; Kim et al., 2019; Young et al., 2015). Several studies argued that employee's environmental values, motives and behavior in terms of learning and applying ideas to develop green products and process, materials recycling and reuses, etc. (Graves and Sarkis, 2018) are essential ingredients that enhances environmental performance and competitiveness of the organization (Kim et al., 2019). Furthermore, we argue that organizations provide incentives and rewards to the employees in order to encourage the environmental friendly activities and environmental behavior (Renwick et al., 2013) namely, pollution prevention, eco innovation, and internalization of environmental management practices (Boiral et al., 2015). Boiral et al. (2015) also argued for personal involvement of top management in environmental training program to send out positive signal to employees about organization's commitment and support for improving environmental performance and competitive advantage vis-àvis rivals in the markets. Using the DC perspective, we predict that firm's intentions to invest their time and resources to immerse employees across numerous environmental training programs for developing dynamic skills, attitudes, and competencies (Helfat and Peteraf, 
2015; Teece, 2014) will improve their environmental performance and competitive advantage. As a result, we propose that:

Hypothesis 4 (H4). Environmental training positively influences firm environmental performance.

Hypothesis 5 (H5). Environmental training positively influences firm competitive advantage.

\subsection{The mediating role of employee environmental training}

The idea of 'Go Green' is yet to become in-built into HR systems in organizations, but several colleagues noted that HR architecture in organizations slowly and steadily started turning to 'green' (Boiral et al., 2015;Jabbour, 2015; Kim et al., 2019). The extant literature on benefits of environmental training is relatively young and scarce which needs attention amongst researchers (Longoni et al., 2018; Sonenshein et al., 2014) as employee's environmental training helps organization towards successfully conservation and recycling of scarce resources and that drives competitive advantage and environmental performance (Boiral et al., 2015; Jabbour, 2015). Therefore, we contend that environmental training drives display green behavior in the workplace (Delmas and Pekovic, 2013) and that in turn influences firms' improved environmental performance and competitive advantage (Jabbour, 2015; Kim et al., 2019).

Drawing upon the RBV and the DC, we posit that environmental training develops employees' cognitive and affective environmental capabilities which are valuable, rare, imperfectly imitable, and nonsubstitutable (Snell et al., 2001a, 2001b; Teece, 2007); and these skilled and competent employees may serve as the basis of organization's sustained environmental performance and competitive advantage (Greening and Turban, 2000; Teece, 2007, 2014). Though environmental training has received scarce attention, it is time for organizations to make a conscious attempt to institutionalize environmental training to all the employees to help them fully understand organization's environmental ethical policies and need to conserve the environment (Kim et al., 2019) that to influence competitive advantage and environmental performance. Several colleagues argued that environmental training is necessary for achieving goals of environmental maturity model (Jabbour, 2015; Wagner, 2013), greening of organizations (Delmas and Pekovic, 2013), execution of environmental policies \& practices (Sarkis et al., 2010), cleaner manufacturing processes \& practices (Gunasekaran and Ngai, 2012); but paradoxically, it has received not enough attention (Jabbour, 2015; Kim et al., 2019; Longoni et al., 2018). Therefore, we predict that:

Hypothesis 6 (H6). Environmental training mediates the relationship between environmental ethics and environmental performance.

Hypothesis 7 (H7). Environmental training mediates the relationship between environmental ethics and competitive advantage.
The Fig. 1 illustrates the conceptual research framework, as:

\section{Methods}

\subsection{Sample details}

We used survey questionnaire to collect perceptions of the middle level managers working across operations, productions, supply chain, environmental clearance, manufacturing and machine maintenance departments of sixteen private, semi-government, and government owned organizations in the United Arab Emirates (UAE). We note that the respondents in the study have had received annually 2-3 environmental awareness training on how to in-built environmental concerns in design systems, processes, and jobs as well as services and products that they sell in the markets. The government of the UAE is very particular about organizations to have clearly laid down policies on environmental ethics and their execution in organizational value creation processes.

To conduct this study, we obtained consent from the human resources (HR) departments the targeted organizations to carry out data collection. However, before the main survey, we conducted a pilot study to ensure that the measuring instruments were valid and reliable. We approached 42 middle level managers of the targeted populations of five organizations to test for the ambiguity, if any, in the framing of the items. Out of total 22 items included in the survey questionnaire, 19 items were found to be unambiguous whereas remaining 3 items were reframed, based on the inputs in the pilot study. In this study, 459 middle level managers participated in the main survey. Altogether, we received 372 filled-in questionnaires from the respondents but only 364 questionnaires were valid for the purpose of examining hypotheses of the study.

As per Latan (2018) suggestion, we examined for sampling characteristics namely, the non-response bias and the common method bias. We performed the independent $t$-test between early respondents (i.e., those who responded in the first two weeks) and the late respondents (i.e., those who responded in the last two weeks) to ensure that the sample in the study represents the population from where they were drawn. The independent t-test results suggest that no significant difference exists between the early and the late respondents in terms of their responses to the items in the survey questionnaire. The results in Table 1 indicate significant values $>0.05$ for both early and late respondents on the variables tested in this study and attest to generalization of results of the study to the large population as they have same sampling weight (Becker and Ismail, 2016). Furthermore, we examined data for the common method bias using the Average Full Collinearity VIF (Kock, 2017) wherein AFVIF was found $1.896<3.3$ that suggests that common-method bias does not affect the obtained results in this study. Furthermore, we checked for the minimum sample size using Cochran's sample size formula followed by Cochran's correction formula as mentioned in Bartlett et al. (2001) that was found as 209

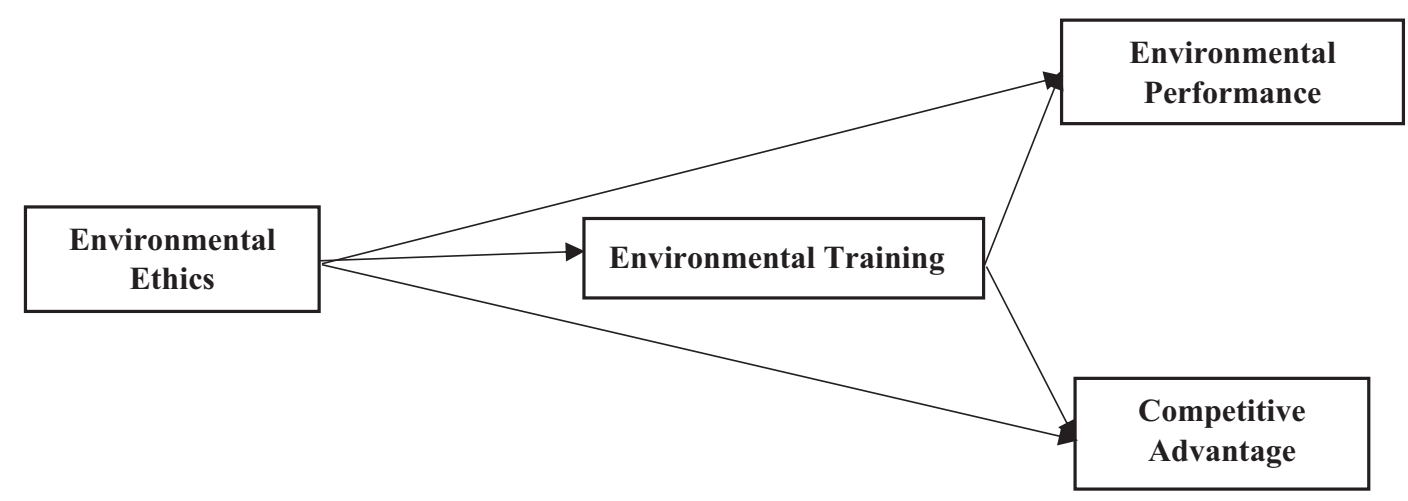

Fig. 1. Proposed research framework. 
Table 1

Non-response bias test.

\begin{tabular}{lll}
\hline Construct & Sig. Levene's test & $\begin{array}{l}\text { Sig. } t \text {-test for equality of } \\
\text { means }\end{array}$ \\
\hline Environmental ethics (EETH) & 0.349 & 0.754 \\
Environmental training (ETRG) & 0.311 & 0.738 \\
Environmental performance & 0.240 & 0.512 \\
$\quad$ (EPERF) & & 0.149 \\
Competitive advantage (COMPAD) & 0.197 & \\
\hline
\end{tabular}

Table 2

Sample and organization details.

\begin{tabular}{|c|c|c|}
\hline Variables & Sample $(n=364)$ & Percentage (\%) \\
\hline \multicolumn{3}{|l|}{ Gender (subordinate) } \\
\hline Male & 191 & 52.47 \\
\hline Female & 173 & 47.53 \\
\hline \multicolumn{3}{|l|}{ Age } \\
\hline$\leq 30$ years & 57 & 15.66 \\
\hline $31-35$ years & 134 & 36.81 \\
\hline $36-40$ years & 106 & 29.12 \\
\hline 41 years and above & 67 & 18.41 \\
\hline \multicolumn{3}{|l|}{ Industry } \\
\hline Healthcare & 108 & 29.67 \\
\hline Oil \& gas & 96 & 26.37 \\
\hline Logistics & 74 & 20.33 \\
\hline Telecommunication & 86 & 23.63 \\
\hline \multicolumn{3}{|l|}{ Education } \\
\hline High school & 24 & 6.59 \\
\hline Diploma & 31 & 8.52 \\
\hline Bachelor degree & 159 & 43.68 \\
\hline Master degree & 134 & 36.81 \\
\hline Ph.D. degree & 16 & 4.40 \\
\hline \multicolumn{3}{|l|}{ Organization type } \\
\hline Private & 102 & 28.02 \\
\hline Semi-government & 78 & 21.43 \\
\hline Public & 184 & 50.55 \\
\hline \multicolumn{3}{|l|}{ Organization size } \\
\hline$\leq 1000$ employees & 97 & 26.65 \\
\hline $1001-5000$ employees & 173 & 47.53 \\
\hline$\geq 5001$ employees & 94 & 25.82 \\
\hline
\end{tabular}

(wherein, margin of error $=0.03$; alpha value $=0.01$ ). However, the sample size of our study is 364 that meets the minimum required sample size (Bartlett et al., 2001). Table 2 presents summary of the sample details.

Table 2 shows that the respondents in this study consisted of $52.47 \%$ male and $47.53 \%$ female, with $52.47 \%$ of the sample were of 35 years of age and below. The respondents in the study were highly educated, as approximately $85 \%$ of them had bachelor to Ph.D. level of educational qualifications in the science $\&$ technology, business and social sciences disciplines. Furthermore, $29.67 \%$ of the sample worked in healthcare, $26.37 \%$ in oil \& gas, $20.33 \%$ in logistics, and $23.63 \%$ in the telecommunication sector. The Table 2 also shows that $26.65 \%$ of the sample were working in organizations with up to 1000 employees, whereas $47.53 \%$ of the respondents were from organizations that had over 1000 and up to 5000 employees, and the remaining $25.82 \%$ of the respondents were working organizations with above 5001 employees at the time of data collection.

\subsection{Measures}

We collected responses from the respondents on seven-point rating scale (where $1=$ low and $7=$ high) for each of the items of environmental ethics, environmental training, environmental performance and competitive advantage scales.

\subsubsection{Environmental ethics (EETH)}

The EETH scale had four items adopted from Henriques and Sadorsky (1999) wherein sample item included was, 'My organization has clear and concrete environmental policies'. The Cronbach alpha and composite reliability of the scale were 0.849 and 0.881 , respectively (see Table 3). The goodness of fit indices of the EETH measurement scale $\quad\left(\chi^{2} / \mathrm{df}=0.002, \quad p<0.967 ; \quad\right.$ CFI $=1.00 ; \quad$ TLI $=0.998$; SRMR $=0.001$; RMSEA $=0.000$ ) were in the acceptable range.

\subsubsection{Environmental training (ETRG)}

The ETRG scale had five items adopted from Daily et al. (2007) and Curkovic (1998). The sample item of ETRG scale was 'I get opportunities to use my environment training in the job'. The Cronbach alpha and composite reliability for the ETRG scale were 0.787 and 0.801 , respectively (see in Table 3). The goodness of fit indices for the ETRG scale $\quad\left(\chi^{2} / \mathrm{df}=1.814, \quad p<0.087 ; \quad\right.$ CFI $=0.989 ; \quad$ TLI $=0.984$; SRMR $=0.041$;MSEA $=0.054)$ were in the satisfactory range.

Table 3

Convergent validity test.

\begin{tabular}{|c|c|c|c|c|c|c|}
\hline & Indicators & Std loading & Variance & Error & SCR & AVE \\
\hline Environmental ethics & My organization has clear and concrete... & & & & 0.881 & 0.651 \\
\hline \multirow[t]{4}{*}{ (Cronbach's alpha $=0.849)$} & ...environmental policies (EETH1) & 0.824 & 0.679 & 0.321 & & \\
\hline & ...polices for environmental investment and procurement (EETH2) & 0.869 & 0.755 & 0.245 & & \\
\hline & ...environmental vision and mission integrated in its marketing events (EETH3) & 0.782 & 0.612 & 0.388 & & \\
\hline & ...environmental vision and mission integrated to its organizational culture (EETH4) & 0.746 & 0.557 & 0.443 & & \\
\hline \multirow{4}{*}{$\begin{array}{l}\text { Environmental training } \\
\quad(\text { Cronbach's alpha }=0.787)\end{array}$} & Employee in this organization... & & & & 0.801 & 0.580 \\
\hline & ...receives adequate environmental training (ETRG1) & 0.800 & 0.640 & 0.36 & & \\
\hline & ...is satisfied with environmental training (ETRG2) & 0.764 & 0.584 & 0.416 & & \\
\hline & ...frequently undergoes environmental training (ETRG3) & 0.718 & 0.516 & 0.494 & & \\
\hline \multirow{7}{*}{$\begin{array}{l}\text { Competitive advantage } \\
\quad(\text { Cronbach's alpha }=0.822)\end{array}$} & My organization's... & & & & 0.886 & 0.563 \\
\hline & ...products/services are better than its competitors (COMPAD1) & 0.741 & 0.549 & 0.451 & & \\
\hline & ...R\&D capabilities are better than its competitors (COMPAD2) & 0.741 & 0.549 & 0.451 & & \\
\hline & ...managerial capabilities are better than its competitors (COMPAD3) & 0.728 & 0.53 & 0.47 & & \\
\hline & ...profitability is better than its competitors (COMPAD4) & 0.744 & 0.554 & 0.446 & & \\
\hline & ...image is better than its competitors (COMPAD5) & 0.773 & 0.598 & 0.402 & & \\
\hline & ...competitive advantage is better than its competitors (COMPAD6) & 0.775 & 0.601 & 0.399 & & \\
\hline \multirow{5}{*}{$\begin{array}{l}\text { Frim environmental performance } \\
\quad(\text { Cronbach's alpha }=0.803 \text { ) }\end{array}$} & Environmental activities pursued by my organization have significantly improved... & & & & & \\
\hline & ...product/process quality (EPERF3) & 0.79 & 0.624 & 0.376 & 0.851 & 0.589 \\
\hline & ...reputation of my company (EPERF4) & 0.815 & 0.664 & 0.336 & & \\
\hline & ...selling products/services (EPERF6) & 0.737 & 0.543 & 0.457 & & \\
\hline & ...reduced overall costs (EPERF7) & 0.723 & 0.523 & 0.477 & & \\
\hline
\end{tabular}




\subsubsection{Environmental performance (EPERF)}

The EPERF scale had seven items adopted from Daily et al. (2007) and Melnyk et al. (2003) and sample item included was "Environmental activities in my organization has significantly improved product/process quality". However, after the confirmatory factor analysis (CFA), the EPERF scale had only four items as the other three items were deleted to arrive at satisfactory goodness of fit indices. The Cronbach alpha and composite reliability of EPERF scale were 0.803 and 0.851 , respectively (see Table 3). A CFA with the items loading on the construct of environmental performance indicated $\left(\chi^{2} / \mathrm{df}=1.972, \quad p<0.139\right.$; $\mathrm{CFI}=0.993$; TLI $=0.979$; $\mathrm{SRMR}=0.029$; $\mathrm{RMSEA}=0.069)$ indicated satisfactory data fit.

\subsubsection{Competitive advantage (COMPAD)}

We adopted six items from Barney (1991), and Porter and van der Linde (1995) to measure firm competitive advantage. The sample item included was 'My organization's products/services are better than its competitors'. The Cronbach alpha coefficient \& composite reliability of COMPAD scale as 0.822 and 0.886 , respectively (see Table 3). Furthermore, the goodness of fit indices for the COMPAD scale $\left(\chi^{2}\right)$ $\mathrm{df}=1.514, \quad p<0.146 ; \quad$ CFI $=0.989 ; \quad$ TLI $=0.979, \quad$ SRMR $=0.041$; RMSEA $=0.050$ ) were in the satisfactory range.

\section{Results}

\subsection{Measurement scale validation}

We applied exploratory factor analysis (EFA) to the observed items of the four constructs to assess for information related to the latent factor and we found moderate to high factor loadings on all the four latent factors. As per the suggestions of Hair et al. (2006), we checked for Cronbach alpha, which ranged from 0.803 to 0.849 , to assess consistency and reliability of the constructs of the study (see Table 3). The Table 3 also shows that the construct validity of the four measuring instruments in this study were in the satisfactory range. For a satisfactory construct validity, the items should load on the intended constructs with standardized loadings $>0.5$ or higher, and ideally 0.7 or higher, the SCR $>0.7$ and the average variance extracted $($ AVE) $>0.5$ (Hair et al., 2006). Table 3 shows that these four measurement scales had high convergent validity (Hair et al., 2006), as the item load on the intended construct had a standardized loading of $\geq 0.704$ to 0.869 , the scale's composite reliability (SCR) was $\geq 0.850$ to 0.886 and the average variance extracted (AVE) was $\geq 0.531$ to 0.651 .

We empirically tested the measurement instruments for the discriminant validity to ensure that the measuring instruments used in this study were not related to each other but actually unrelated. It has been suggested that each of the items of a measuring instrument should have standardized loading of 0.7 or higher and the square root of the AVE for each construct should be greater than any correlation estimate (Fawcett et al., 2009) for a sound discriminant validity. In this study, almost all items loaded on the intended construct had standardized loading of $\geq 0.704$ (see Table 3 ) and the square root of the AVE was found to be $\geq 0.745$ (see Table 4).

\subsection{The structural model}

We performed structural equation modeling (SEM) to examine hypotheses in this study. Table 5 depicts results related to the 'testing for direct effect', whereas the Table 6 presents results for the 'testing for indirect effect'.

\subsubsection{Testing for direct effect}

The results in Table 5 shows that $\mathrm{H} 1$ [COMPAD $\leftarrow$ EETH]; and H2 [EPERF $\leftarrow$ EETH] are supported $(\beta=0.414 ; t=6.226, p<0.001)$ and ( $\beta=0.395 ; t=6.046, p<0.001$ ), respectively. In other words, environmental ethics influences firm's competitive advantage (i.e., H1), environmental performance (i.e., H2). Similarly, H3 [ETRG $\leftarrow$ EETH]; H4 [EPERF $\leftarrow$ ETRG]; and H5 [COMPAD $\leftarrow$ ETRG] are supported $(\beta=0.701 ; \quad t=14.130, \quad p<0.001) ; \quad(\beta=0.354 ; \quad t=5.567$, $p<0.001)$; and $(\beta=0.356 ; t=6.047, p<0.001)$ respectively. These findings suggest that firm environmental ethics positively and significantly impacts on environmental training (i.e., H3), and at the same time, environmental training impacts positively and significantly to environmental performance (i.e., H4) and competitive advantage (i.e., H5) of the firm. Therefore, the H1, H2, H3, H4, and H5 were supported in this study.

\subsubsection{Testing for indirect effect}

The research framework in this study also aimed to investigate the mediating role of employee environmental training between firm environmental ethics on the one hand, and firm environmental performance (i.e., H6) and competitive advantage (i.e., H7) on the other hand. To statistically test the mediation hypotheses, based on 5000 bootstrapped sample, as suggested by Zhao et al. (2010), was performed wherein H6 $[$ EPERF $\leftarrow$ ETRG $\leftarrow$ EETH] and H7 [COMPAD $\leftarrow$ ETRG $\leftarrow$ EETH] are supported $(\beta=0.238$, Lower bound $p<0.001)$ and ( $\beta=0.250, p<0.001)$ respectively. This means that organizational emphasis on environmental training significantly mediates between the influence of firm environmental ethics on the environmental performance; and firm environmental ethics on the competitive advantage. Last, but not the least, we mention here that key indices of the goodness of fit $\quad\left(\chi^{2} / \mathrm{df}=1.239, \quad p<0.288 ; \quad\right.$ CFI $=0.987 ; \quad$ TLI $=964$; SRMR $=0.041$; RMSEA $=0.039$ ) for the whole model are in the acceptable range and supports our proposed research framework of this study.

\section{Discussion and conclusions}

In the 21st century, firms should adopt balanced approach to financial, social, and environmental performance and that calls for increased attention to implementation of environmental management systems (Longoni et al., 2018). Several scholars argue that firms need to have strong environmental ethics in place (Tate and Bals, 2018) to influence environmental management practices for enhanced social and environmental performance (Short et al., 2016; Yawar and Seuring, 2017). Environmental ethics is an intangible asset that firms leverage to increase environmental performance and competitive advantage (Chang, 2011; Chen, 2008). However, there is no straight-line between environmental ethics to environmental performance and competitive

Table 4

Discriminant validity test.

\begin{tabular}{|c|c|c|c|c|c|c|c|}
\hline & & Mean & S.D. & 1 & 2 & 3 & 4 \\
\hline 1 & Environmental ethics (EETH) & 5.29 & 1.39 & $(0.807)$ & & & \\
\hline 2 & Competitive advantage (COMPAD) & 5.10 & 1.27 & $0.755^{* *}$ & $(0.751)$ & & \\
\hline 3 & Environmental training (ETRG) & 5.17 & 1.42 & $0.701^{* *}$ & $0.710^{* * *}$ & $(0.761)$ & \\
\hline 4 & Environmental performance (EPERF) & 5.41 & 1.10 & $0.714^{* *}$ & $0.678^{* *}$ & $0.681^{* * *}$ & $(0.745)$ \\
\hline
\end{tabular}

Note: The diagonal value - italic \& bold - represents square roots of average variance extracted.

${ }^{* *} p<0.001$. 
Table 5

Testing for direct impact.

\begin{tabular}{|c|c|c|c|c|c|}
\hline Relationships & Standardized direct effect & Standard error & $\mathrm{t}$ value & Sig. level & Hypothesis testing \\
\hline $\mathrm{COMPAD} \leftarrow \mathrm{EETH}$ & 0.414 & 0.091 & 6.226 & $p<0.001$ & H1 accepted \\
\hline EPERF $\leftarrow$ EETH & 0.395 & 0.059 & 6.046 & $p<0.001$ & H2 accepted \\
\hline ETRG $\leftarrow$ EETH & 0.701 & 0.038 & 14.130 & $p<0.001$ & H3 accepted \\
\hline EPERF $\leftarrow$ ETRG & 0.354 & 0.075 & 5.567 & $p<0.001$ & H4 accepted \\
\hline COMPAD $\leftarrow$ ETRG & 0.356 & 0.105 & 6.047 & $p<0.001$ & H5 accepted \\
\hline
\end{tabular}

Table 6

Testing for indirect impact.

\begin{tabular}{|c|c|c|c|c|c|}
\hline Relationships & Standardized indirect effect & Sig. level & Lower bound & Upper bound & Hypothesis testing \\
\hline $\mathrm{EPERF} \leftarrow$ ETRG $\leftarrow$ EETH & 0.238 & $p<0.001$ & 0.171 & 0.335 & H6 accepted \\
\hline $\mathrm{COMPAD} \leftarrow \mathrm{ETRG} \leftarrow \mathrm{EETH}$ & 0.250 & $p<0.001$ & 0.167 & 0.337 & H7 accepted \\
\hline
\end{tabular}

advantage and environmental training facilitates the influence of environmental ethics to reduce negative effect of business operations, if any, on the physical and built environment (El-Kassar and Singh, 2018; Graves et al., 2013) and enhance firm's environmental performance and competitive advantage (Singh and El-Kassar, 2019; Thu et al., 2019).

Drawing upon RBV and DC theoretical lenses, we argued that environmental training enhance employees' dynamic capabilities namely, environmental skills, attitudes and knowledge (e.g., Schilke, 2014; Vogel and Güttel, 2013) as such that they act as a source of path dependence to increased competitive advantage and environmental performance of an organization (Helfat and Peteraf, 2015; Teece, 2014). The findings of our study offer key theoretical and practical implications for environmental management practices in organization and are discussed in details.

\subsection{Theoretical contributions}

Our study makes three key theoretical contributions. First, the findings of the study advance RBV and DC perspective on to the linkage between firm's environmental ethics, environmental training, environmental performance and competitive advantage (e.g., Helfat and Peteraf, 2015; Teece, 2014). Therefore, the findings of our study advance RBV and DC that environmental performance and competitive advantage, especially in the context of growing environmental awareness amongst key stakeholders, depends upon effective integration and reconfiguration of firm's key competences namely, environmental ethical policy and its implementation through employee's environmental capabilities (i.e., skills, knowledge and attitudes) (Chang, 2011; El-Kassar and Singh, 2018; Teece, 2014). In particular, the findings of our study show that when organizations have environmental ethical policy play critical role in enhancing firms' environmental performance and competitive advantage directly and also indirectly through developing employee's environmental capabilities - skills, knowledge, and attitudes - through environmental training (e.g., Chang, 2011; Jabbour, 2015; Thu et al., 2019).

Second, our study contributes to advance knowledge in the field of environmental management. We suggest that organization should adopt and implement environmental ethical policy all through varied organizational processes and systems to accrue benefits in the form of enhanced environmental performance and competitive advantage. As such, firm's environmental ethics is a foundation stone for enhanced environmental management at workplace but this connection should be regarded as organizational intentions and attempt to take care of physical and built environment rather than a definitive proposition. Although we recognize that organization's environmental beliefs and their expression in environmental ethical policy and practices remain an underlying perspective, our study suggests that developing employees' environmental capabilities strengthen organizations' resolves to reduce negative effect of their business actions, if any, on built and physical environment in the context of environmental sustainability.

Last, but not the least, our study advances theoretical understanding on the role of environmental training vis-à-vis success of environmental management initiatives of the organizations as evidenced in several studies (e.g., El-Kassar and Singh, 2018; Jabbour, 2015; Singh and ElKassar, 2019). Environmental training is an area that strives to align varied human resource management practices with that of the environmental management in the organization (Jabbour, 2015; Renwick et al., 2013). Our study suggest that the environmental training plays significant role in organization's attempt to reduce pollution, improve product/service quality, reduce overall operating costs, and improve reputation of the company. Therefore, our study suggests that environmental training enhances organization's environmental management goals and that affects competitive advantage. As a result, we suggest that environmental training aims at developing employee's environmental capabilities and serves as a source of path dependence to enhanced environmental performance and competitive advantage (e.g., Helfat and Peteraf, 2015; Teece, 2014).

Overall, the findings of our study have varied suggestions for researches on environmental management in the organization as greater understanding of the role of employee's dynamic environmental capabilities could lead to greater understanding of firm's performance outcomes from their environmental efforts. We believe that the findings of our study will stir up researcher's curiosity to unravel the human side of environmental management and that will surely steer future researches in significant directions.

\subsection{Managerial implications}

Our study makes several important managerial implications to address increased environmental pressures, as they cannot afford to ignore the environmental concerns of key stakeholders.

Firstly, firms have had been witnessing increased stakeholders pressure for creating sustainable environmental management practices to reduce negative impacts of business on the built and the physical environment (Longoni et al., 2018; Yu et al., 2017). In such a business scenario, our study suggests that both top management and employees should be committed implement and sustain environmental ethical practices to enhance firm's environmental performance and competitive advantage. Furthermore, our study suggests that as the top management keep their employees engaged and monitor their job behaviors vis-à-vis sustainable environmental management practices anchored on environmental ethics, it not only enhances firm environmental performance but the latter in turn positively influences competitive advantage over the rivals in the markets. In other words, our study suggests that organization's approach towards environmental ethical practices at workplace should be not be reactive but proactive with intentions to 
create and sustain synergy amongst the triads namely, profits, the society, and the environment.

Such environmental beliefs, values, and behaviors of organization asks top management to enable employees to carry out environmental agenda meticulously in what they do in their assigned tasks and that is the second implication of our study for managerial practices. We suggest that organization's commitment to environmental ethics will remain ornaments hanging on the walls or in the files until organization makes conscious decisions to develop employee's environmental capabilities to carry out such a noble mission. Therefore, the findings of our study calls upon organization to allocate significant percentage of its annual budget and other relevant resources for environmental training and development programs with clear goal to develop employee's environmental cognitive capabilities and behavioral competencies for enhancing and sustaining firm's environmental performance and competitive advantage. We also suggest that such employee's environmental training should not be one-off event but a continuous process to satisfy their key stakeholders and also to beat competitions from the rivals in the dynamic markets.

Last, but not the least, we suggest that firms should tune up their employee recruitment \& selection strategy that should be aligned with organization's environmental ethical agenda for sustained proactive environmental management practices at workplace. Furthermore, we suggest that top management should adopt a performance appraisal system wherein employee's environmental job behaviors receive significant weight and linked with organization's reward management practices for employees to exhibit environmental job behaviors repeatedly and continuously. In other words, we suggest that all three bundles of HR practices - the boundary spanning HR practices (e.g., recruitment \& selection), the development HR practices (e.g., training \& development), and the maintenance HR practices (e.g., performance appraisal, and rewards management) - should work synergistically for sustainable environmental management practices in the organization.

We believe that the seamless synergy of aforementioned three bundles of HR practices under the umbrella of environmental ethics will make business, society, and planet to coexist and always be happy and healthy.

\subsection{Limitations and direction for future research}

Like any other study, this study is not without limitations. First, the study relied primarily on the perceptual measures of the constructs that are commonly used in the management literature. Future research should use objective measures along with perceptual measures, especially for the constructs of environmental performance and competitive advantage. Second, we used employee environmental training as a mediator to investigate onto the indirect effect of firm environmental ethics on environmental performance and competitive advantage. We suggest that the future study should use all ability, motivation and opportunity based human resource practices (e.g., recruitment \& selection, training, performance appraisal, teamwork, reward systems, employee relations, etc.) to investigate on how they mediate on to the influence of organization's environmental ethics on their environmental performance and competitive advantage. Third, we tested our proposed theoretical model in the UAE. Therefore, we suggest that future research should use our research model and examine it in the wider context by drawing upon sample from other countries of the Gulf region to advance theory and practice of environmental management.

\section{References}

Abdelzaher, D.M., Abdelzaher, A., 2017. Beyond environmental regulations: exploring the potential of "eco-Islam" in boosting environmental ethics within SMEs in Arab markets. J. Bus. Ethic. 145 (2), 357-371.

Adner, R., Helfat, C.E., 2003. Corporate effects and dynamic managerial capabilities. Strateg. Mang. J. 24 (10), 1011-1025.

Ahmed, N.U., Montagno, R.V., Firenze, R.J., 1998. Organizational performance and environmental consciousness: an empirical study. Manag. Decis. 36 (2), 57-62.

Alt, E., Díez-de-Castro, E.P., Lloréns-Montes, F.J., 2015. Linking employee stakeholders to environmental performance: the role of proactive environmental strategies and shared vision. J. Bus. Ethics 128 (1), 167-181.

Anton, W.R.Q., Deltas, G., Khanna, M., 2004. Incentives for environmental self-regulation and implications for environmental performance. J. Environ. Econ. Manag. 48 (1), 632-654.

Aragón-Correa, J., Hurtado-Torres, N., Sharma, S., García-Morales, V.J., 2008. Environmental strategy and performance in small firms: a resource-based perspective. J. Environ. Manag. 86, 88-103.

Barney, J., 1991. Firm resources and sustained competitive advantage. J. Manag. 17 (1), 99-120.

Bartlett, J.E., Kotrilk, J.W., Higgins, C.C., 2001. Organizational research: determining appropriate sample size in survey research. Inf. Technol. Learn. Perform. J. 19 (1), 43-50.

Becker, J.-M., Ismail, I.R., 2016. Accounting for sampling weights in PLS path modeling: simulations and empirical examples. Eur. Manag. J. 34 (6), 606-617.

Boiral, O., Talbot, D., Paillé, P., 2015. Leading by example: a model of organizational citizenship behavior for the environment. Bus. Strateg. Environ. 24 (6), 532-550.

Cassells, S., Lewis, K.V., 2017. Environmental management training for micro and small enterprises: the missing link? J. Small Bus. Enterp. Dev. 24 (2), 297-312.

Chan, R.Y.K., 2005. Does the natural-resource-based view of the firm apply in an emerging economy? A survey of foreign invested enterprises in China. J. Manag. Stud. 42 (3), 625-672.

Chang, C.H., 2011. The influence of corporate environmental ethics on competitive advantage: the mediation role of green innovation. J. Bus. Ethics 104 (3), 361-370.

Chen, Y.S., 2008. The positive effect of green intellectual capital on competitive advantages of firms. J. Bus. Ethics 77 (3), 271-286.

Chen, Y.S., Lai, S.B., Wen, C.T., 2006. The influence of green innovation performance on corporate advantage in Taiwan. J. Bus. Ethics 81 (3), 531-543.

Chen, Y., Tang, G., Jin, J., Li, J., Paillé, P., 2015. Linking market orientation and environmental performance: the influence of environmental strategy, employee's environmental involvement, and environmental product quality. J. Bus. Ethics 127 (2), $479-500$.

Christmann, P., 2000. Effects of "best practices" of environmental management on cost advantage: the role of complementary assets. Acad. Manag. J. 43, 663-680.

Chuang, S.P., Huang, S.J., 2018. The effect of environmental corporate social responsibility on environmental performance and business competitiveness: the mediation of green information technology capital. J. Bus. Ethics 150 (4), 991-1009.

Curkovic, S., 1998. Investigating the Linkage between Total Quality Management and Environmentally Responsible Manufacturing, UMI No. 9839628. (UMI Dissertation Services, Ann Arbor, MI).

Daily, B.F., Bishop, J.W., Steiner, R., 2007. The mediating role of EMS teamwork as it pertains to HR factors and perceived environmental performance. J. Appl. Bus. Res. 23 (1), 95-109.

Daily, B.F., Bishop, J.W., Massoud, J.A., 2012. The role of training and empowerment in environmental performance: a study of the Mexican maquiladora industry. Int. J. Oper. Prod. Manag. 32 (5), 631-647.

Delmas, M.A., Pekovic, S., 2013. Environmental standards and labor productivity: understanding the mechanisms that sustain sustainability. J. Organ. Behav. 34 (2), 230-252.

Dubey, R., Gunasekaran, A., Ali, S.S., 2015. Exploring the relationship between leadership, operational practices, institutional pressures and environmental performance: a framework for green supply chain. Int. J. Prod. Econ. 160, 120-132.

Dubey, R., Gunasekaran, A., Helo, P., Papadopoulos, T., Childe, S.J., Sahay, B.S., 2017. Explaining the impact of reconfigurable manufacturing systems on environmental performance: the role of top management and organizational culture. J. Clean. Prod. $141,56-66$.

Dumont, J., Shen, J., Deng, X., 2017. Effects of green HRM practices on employee workplace green behavior: the role of psychological green climate and employee green values. Hum. Resour. Manag. 56 (4), 613-627.

Eisenhardt, K., Martin, J., 2000. Dynamic capabilities: what are they? Strateg. Manag. J. $21(10-11), 1105-1121$.

El-Kassar, A.N., Singh, S.K., 2018. Green innovation and organizational performance: the influence of big data and the moderating role of management commitment and HR practices. Technol. Forecast. Soc. Chang. https://doi.org/10.1016/j.techfore.2017. 12.016. (Online).

Famiyeh, S., Adaku, E., Amoako-Gyampah, K., Asante-Darko, D., Amoatey, C.T., 2018 Environmental management practices, operational competitiveness and environmental performance: empirical evidence from a developing country. J. Manuf Technol. Manag. 29 (3), 588-607.

Fawcett, S.E., Wallin, C., Allred, C., Magnan, G., 2009. Supply chain information sharing: benchmarking a proven path. Benchmark. Int. J. 16 (2), 222-246.

Graves, L.M., Sarkis, J., 2018. The role of employees' leadership perceptions, values, and motivation in employees' provenvironmental behaviors. J. Clean. Prod. 196, $576-587$.

Graves, L.M., Sarkis, J., Zhu, Q., 2013. How transformational leadership and employee motivation combine to predict employee pro-environmental behaviors in China. J. Environ. Psychol. 35, 81-91.

Greening, D.W., Turban, D.B., 2000. Corporate social performance as a competitive advantage in attracting a quality workforce. Bus. Soc. 39 (3), 254-280.

Guerci, M., Longoni, A., Luzzini, D., 2016. Translating stakeholder pressures into environmental performance - the mediating role of green HRM practices. Int. J. Hum. Resour. Manag. 27 (2), 262-289.

Gunasekaran, A., Ngai, E.W.T., 2012. The future of operations management: an outlook and analysis. Int. J. Prod. Econ. 135, 687-701. 
Hair, J.F., Black, W.C., Babin, B.J., Anderson, R.E., Tatham, R.L., 2006. Multivariate data analysis. vol. 6 Pearson Prentice Hall, Upper Saddle River, NJ.

Helfat, C.E., Peteraf, M.A., 2015. Managerial cognitive capabilities and the microfoundations of dynamic capabilities. Strateg. Manag. J. 36 (6), 831-850.

Henriques, I., Sadorsky, P., 1999. The relationship between environmental commitment and managerial perceptions of stakeholder importance. Acad. Manag. J. 42 (1), 87-99.

Jabbour, C.J.C., 2015. Environmental training and environmental management maturity of Brazilian companies with ISO14001: empirical evidence. J. Clean. Prod. 96, 331-338.

Jabbour, C.J., Santos, F.C.A., Nagano, M.S., 2010. Contributions of HRM throughout the stages of environmental management: methodological triangulation applied to companies in Brazil. Int. J. Hum. Resour. Manag. 21, 1049-1089.

Jabbour, C.J.C., Sarkis, J., de Sousa Jabbour, A.B.L., Renwick, D.W.S., Singh, S.K., Grebinevych, O., Kruglianskas, I., Godinho Filho, M., 2019. Who is in charge? A review and a research agenda on the 'human side' of the circular economy. J. Clean. Prod. 222, 793-810.

Ji, L., Huang, J., Liu, Z., Zhu, H., Cai, Z., 2012. The effects of employee training on the relationship between environmental attitude and firms' performance in sustainable development. Int. J. Hum. Resour. Manag. 23 (14), 2995-3008.

Kassinis, G., Vafeas, N., 2006. Stakeholder pressures and environmental performance. Acad. Manag. J. 49 (1), 145-159.

Kim, Y.J., Kim, W.G., Choi, H.M., Phetvaroon, K., 2019. The effect of green human resource management on hotel employees' eco-friendly behavior and environmental performance. Int. J. Hosp. Manag. 76, 83-93.

Kock, N., 2017. Common methods bias: A full collinearity assessment method for PLSSEM. In: Latan, H., Noonan, R. (Eds.), Partial Least Squares Path Modeling: Basic Concepts, Methodological Issues and Applications. Springer International Publishing, Cham.

Latan, H., 2018. PLS path modeling in hospitality and tourism research: the golden age and days of future past. In: Ali, F., Rasoolimanesh, M.S., Cobanoglu, C. (Eds.), Applying Partial Least Squares in Tourism and Hospitality Research. Emerald, Bingley, pp. 53-83.

Lee, J.W., Kim, Y.M., Kim, Y.E., 2018. Antecedents of adopting corporate environmental responsibility and green practices. J. Bus. Ethics 148 (2), 397-409.

Longoni, A., Luzzini, D., Guerci, M., 2018. Deploying environmental management across functions: the relationship between green human resource management and green supply chain management. J. Bus. Ethics 151 (4), 1081-1095.

Melnyk, S.A., Sroufe, R.P., Calantone, R., 2003. Assessing the impact of environmental management systems on corporate and perceived environmental performance. J. Oper. Manag. 21, 329-351.

Nejati, M., Rabiei, S., Jabbour, C.J.C., 2017. Envisioning the invisible: understanding the synergy between green human resource management and green supply chain management in manufacturing firms in Iran in light of the moderating effect of employees' resistance to change. J. Clean. Prod. 168, 163-172.

O'Donohue, W., Torugsa, N., 2016. The moderating effect of 'green' HRM on the association between proactive environmental management and financial performance in small firms. Int. J. Hum. Resour. Manag. 27 (2), 239-261.

Peng, Y.S., Lin, S.S., 2008. Local responsiveness pressure, subsidiary resources, green management adoption and subsidiary's performance: evidence from Taiwanese manufactures. J. Bus. Ethics 79, 199-212.

Ployhart, R.E., 2012. The psychology of competitive advantage: an adjacent possibility Ind. Organ. Psychol. 5 (1), 62-81.

Porter, M.E., van der Linde, C., 1995. Green and competitive: ending the stalemate. Hary. Bus. Rev. 73 (5), 120-134.

Renwick, D.W., Redman, T., Maguire, S., 2013. Green human resource management: a review and research agenda. Int. J. Manag. Rev. 15 (1), 1-14.

Sarkis, J., González-Torre, P., Adenso-Díaz, B., 2010. Stakeholder pressure and the adoption of environmental practices: the mediating effect of training. J. Oper. Manag 28 (2), 163-176.

Schilke, O., 2014. On the contingent value of dynamic capabilities for competitive advantage: the nonlinear moderating effect of environmental dynamism. Strateg. Manag. J. 35 (2), 179-203.

Short, J.C., McKenny, A.F., Ketchen, D.J., Snow, C.C., Hult, G.T.M., 2016. An empirica examination of firm, industry, and temporal effects on corporate social performance. Bus. Soc. 55 (8), 1122-1156.

Singh, S.K., El-Kassar, A.N., 2019. Role of big data analytics in developing sustainable capabilities. J. Clean. Prod. 213, 1264-1273.

Snell, S.A., Shadur, M.A., Wright, P.M., 2001a. The era of our ways. In: Hitt, M.A., Freeman, R.E., Harrison, J.S. (Eds.), Handbook of Strategic Management. Blackwell Publishing, Oxford, pp. 627-629.

Snell, S.A., Stueber, D., Lepak, D.P., 2001b. Virtual HR departments: getting out of the middle. In: Heneman, R.L., Greenberger, D.B. (Eds.), Human Resource Management in Virtual Organizations. Information Age Publishing, Greenberg.

Sonenshein, S., DeCelles, K., Dutton, J., 2014. It's not easy being green: self-evaluations and their role in explaining support of environmental issues. Acad. Manag. J. 57, 17-37.

Sugita, M., Takahashi, T., 2015. Influence of corporate culture on environmental management performance: an empirical study of Japanese firms. Corp. Soc. Responsib. Environ. Manag. 22 (3), 182-192.

Sung, S.Y., Choi, J.N., 2018. Effects of training and development on employee outcomes and firm innovative performance: moderating roles of voluntary participation and evaluation. Hum. Resour. Manag. 57 (6), 1339-1353.

Tate, W.L., Bals, L., 2018. Achieving shared triple bottom line (TBL) value creation: toward a social resource-based view (SRBV) of the firm. J. Bus. Ethics 152 (3), 803-826.

Teece, D.J., 2007. Explicating dynamic capabilities: the nature and microfoundations of (sustainable) enterprise performance. Strateg. Manag. J. 28 (13), 1319-1350.

Teece, D.J., 2014. The foundations of enterprise performance: dynamic and ordinary capabilities in an (economic) theory of firms. Acad. Manag. Perspect. 28 (4), $328-352$.

Thu, P.D.D., Paillé, P., Halilem, N., 2019. Systematic review on environmental innovativeness: a knowledge-based resource view. J. Clean. Prod. 211, 1088-1099.

Vogel, R., Güttel, W.H., 2013. The dynamic capability view in strategic management: a bibliometric review. Int. J. Manag. Rev. 15 (4), 426-446.

Wagner, M., 2013. Green human resource benefits: do they matter as determinants of environmental management system implementation? J. Bus. Ethics 114, 443-456.

Wagner, M., Van, P.N., Wehrmeyer, W., 2002. The relationship between the environmental and economic performance of firms: an empirical analysis of the European paper industry. Corp. Soc. Responsib. Environ. Manag. 9, 133-146.

Wang, C.Y.P., Jaw, B.S., Tsai, C.H.C., 2012. Building dynamic strategic capabilities: a human capital perspective. Int. J. Hum. Resour. Manag. 23 (6), 1129-1157.

Weaver, G.R., Trevino, L.K., Cochran, P.L., 1999. Corporate ethics programs as control systems: influences of executive commitment and environmental factors. Acad. Manag. J. 42, 41-57.

Wright, P.M., Dunford, B.B., Snell, S.A., 2001. Human resources and the resource based view of the firm. J. Manag. 27 (6), 701-721.

Yawar, S.A., Seuring, S., 2017. Management of social issues in supply chains: a literature review exploring social issues, actions and performance. J. Bus. Ethics 141 (3), 621-643.

Young, W., Davis, M., McNeill, I.M., Malhotra, B., Russell, S., Unsworth, K., Clegg, C.W., 2015. Changing behaviour: successful environmental programmes in the workplace. Bus. Strateg. Environ. 24 (8), 689-703.

Yu, W., Ramanathan, R., Nath, P., 2017. Environmental pressures and performance: an analysis of the roles of environmental innovation strategy and marketing capability. Technol. Forecast. Soc. Chang. 117, 160-169.

Zhao, X., Lynch Jr., J.G., Chen, Q., 2010. Reconsidering Baron and Kenny: myths and truths about mediation analysis. J. Consum. Res. 37 (2), 197-206.

Zhu, Q., Geng, Y., Fujita, T., Hashimoto, S., 2010. Green supply chain management in leading manufacturers: case studies in Japanese large companies. Manag. Res. Rev. 33 (4), 380-392.

Sanjay Kumar Singh, Ph.D., is Associate Professor of Management, College of Business, Abu Dhabi University, Abu Dhabi, UAE. His research interests include big data analytics, knowledge management, innovation management, sustainability, international HRM and Global mobility and talent management. He can be reached at sanjay.singh@adu.ac.ae.

Jin Chen, Ph.D. is Professor of Innovation, Entrepreneurship and Strategy, School of Economics and Management, Tsinghua University, Beijing, China. His research interests include technology innovation, innovation management, entrepreneurial innovativeness and knowledge management. He can be reached at chenjin@sem.tsinghua.edu.cn.

Manlio Del Giudice, Ph.D. is Professor of Management, University of Rome "Link Campus" in Italy. He is also a Research Full Professor of Entrepreneurship and Management at the Paris School of Business, in Paris, France. His research interests in clude knowledge management, entrepreneurship, technology transfer, cross-cultural management. He can be reached at manlio.delgiudice@oasipc.com.

Abdul-Nasser El-Kassar, $\mathrm{Ph} . \mathrm{D}$. is Associate Professor of Quantitative Methods, Adnan Kassar School of Business, Lebanese American University, Beirut, Lebanon. His research areas include cryptography, abstract algebra, number theory, and big data analytics. He can be reached atabdulnasser.kassar@lau.edulb. 